\title{
Metamorphic Moment of the Indian Polity: Anatomizing the Evolution and Changing Dynamics of the Indian State against the Protean Nature of Cooperative Federalism
}

\author{
Abhigyan Guha \\ Post-Graduate Student at the Department of International Relations, Jadavpur University, \\ DL-230/5, Sector-II, Salt Lake, Kolkata-700091
}

\begin{abstract}
The elusive and paradoxical nature of Indian polity has been evident in the amalgamation of Western patterns of bureaucratic organization, participatory politics with indigenous practices and institutional framework that had an organic growth on the Indian soil. While post-colonial India was characterized by the incorporation of democratic political ethos and structural architecture, Westminster model of parliamentary government and representative legal institutions, it did not imply the exact replication of the British architectonic system of advanced industrial democracy. As the Indian political process is subjected to dramatic transmutations and cyclical changes, it has eventually acquired a mass character and vibrancy with the exuberant participation of marginalized and underprivileged political formations and social groups in the political arena, coupled with the regionalization of the polity, altering the terms of political domination and sowing the seeds of an increasingly complex mechanism of negotiation, competitive bargaining, alliance and coalition-building, in a cooperative federalist arrangement. The principle objective of this paper is to put an emphasis on the role of the Indian state, the transformation of Indian federalism and the political process, while holistically encapsulating the development and multidimensional patterns associated with the Indian political system, tracing the departure from the heyday of the Congress system and Nehruvian civic nationalism to the crystallization of a majoritarian edifice, propelled by Hindu Nationalism.
\end{abstract}

KEYWORDS: Political system; Participatory politics; Indian state; Federalism; Hindu Nationalism

\section{INTRODUCTION}

The Indian political system has undergone a plethora of changes ever since its independence and decolonization, and has re-oriented itself according to the dynamic nature of social and political forces, thereby re-calibrating its governmentality, policy formulation, decision making and the degree of democratization. The increasingly heterogeneous and multicultural pluralistic character of India's political establishment and social fabric, notwithstanding the macroscopic ideological consensus during India's National Movement and its subsequent independence from centuries of British colonial rule, was reflected in the antithetical reconciliation of democracy and capitalism on one hand, and parliamentarism and federalism on the other hand, that characterized the foundational pillars and centre of gravity of Indian political process. (Singh, 2017) The ever-changing and continuously shifting complexities of the socioeconomic processes and cultural circumstances enmeshed in the political realm, manifested in the dialectical interaction between society and politics shaped the evolution of the Indian political system in its articulation and manifestation. (Chakrabarty, 2008) Postcolonial India had inherited the structural and institutional framework of governance and policymaking from the British colonial administration, and its independence was marked by radical reconstruction of territorial boundaries, significant changes in the state architecture, with the inauguration of a sovereign republic, post-Partition and constitution enactment. (Chatterjee, 2010)

Quite interestingly, as the fundamental apparatus of governmental administration, bureaucracy, basic structure of civil and criminal law and its administration was bequeathed to India from the colonial rule, myriad institutional changes were incorporated into the Indian statecraft simultaneously, namely-- the provision of a sovereign legislature characterized by universal adult franchise sans communal representation; constitutionally granted and guaranteed set of political rights and civil liberties in the form of Fundamental Rights, Fundamental Duties; constitutionally envisaged system of reservation backed by affirmative action for the Scheduled Castes (SCs), Scheduled Tribes (STs) and Other Backward Classes (OBCs); a robust parliamentary system of government that was modeled 


\section{International Journal of Current Science Research and Review}

ISSN: 2581-8341

Volume 04 Issue 06 June 2021

DOI: 10.47191/ijcsrr/V4-i6-03, Impact Factor: 5.825

IJCSRR@ 2021

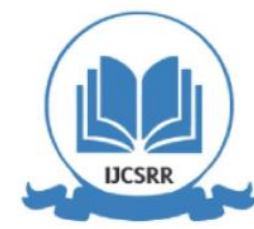

www.ijcsrr.org

on the British Westminster pattern of parliamentary democracy, consisting of an elected executive responsible to the legislature and vice-versa with the elements of collective responsibility and individual responsibility and an indirectly elected President as the de jure head of the state; independent single integrated judiciary with the Supreme Court at the apex, vested with the powers of judicial review of the parliamentary laws; a constitutionally affirmed federal system of government with an unitary bias, viz. a dual polity of distribution of power between the centre and the state governments, wherein the centre is more centralized than federations elsewhere in the world. (Ibid)

\section{BACKGROUND: STATE, FEDERALISM AND THE INDIAN POLITICAL PROCESS}

Embodying the elements of modern citizenship and democratic decision-making, the Indian state as a cardinal actor in the political process was faced with the daunting task of managing law and order, security, balancing command and control while acting as a catalyst for the construction of a unified nation-state and ensuring macro-societal transformation, confronted with debilitating historical circumstances of Partition and acute instability in the wake of Indian National Congress' (INC) division, conflicts with Pakistan, integration of multiple princely states, linguistic and regional agitations especially in Telengana, coupled with extreme poverty and unemployment, struggling to establish political authority over its vast territory and diverse population. In the paradigmatic shift from colonialism to a nascent multi-party parliamentary democracy, the utmost priority was given on holding a linguistically and culturally heterogeneous and economically disparate land together, and in following such a goal, the Indian leadership had adopted the ideology of composite nationalism in order to coalesce and amalgamate all strands of people into the national fold. (Mitra, 2017)

In this regard, the linguistic reorganization of Indian states in 1956 was a milestone in moulding and shaping future institutional arrangements, leading to the significant expansion and consolidation of a robust federal democracy. Focusing on societal transformation, the ruling political elites of the Indian political establishment were committed to the construction of a developmental state, while stimulating growth in the economy, and in this context, the fundamental needs of the Indian population were incorporated as growth, equality and justice, with an added emphasis on heavy industry, relative de-emphasis on agriculture, as the central government had been limited by the constitutional restrictions in the rural sector, where respective state governments were assigned the responsibility of conducting land reforms. However, there had been an obstruction and organized resistance from the landed elites against the massive changes in the social order and the political system in a dramatic fashion, thereby systematically hampering any egalitarian redistribution of assets and resources. (Ibid) Historically, India had strong democratic roots, amidst political turbulences at the national and regional levels pertaining to legitimacy, accountability, responsiveness and leadership, and has managed to consolidate its democratic foundation, despite socio-economic challenges, the alternating currents of powerlessness, centralization and decentralization, and continuous re-configuration of its federal framework as an accommodative reconciliatory instrument. Initially plagued with the predicament of low level of political mobilization and agglomeration, political conflicts over claims and counterclaims surrounding the share of power and resources through the central government were common in the Indian political system, which was resolved by the recognition of linguistic communities as legitimate form of political components and class conflicts between the regional elites and the peripherally marginalized had been mitigated by accommodating heterogeneity within the federal system. (Kohli, 2009) Representing an increasingly competitive multi-party functional democracy, the Indian party system dominated by myriad political and social cross-cutting ties and cleavages, has managed to exhibit a sense of dynamic equilibrium and structural continuity, vis-à-vis social mobilization, representation, policy formulation and implementation, with a broad-based historical consensus among political leadership on the principle parameters of the ecosystem in which the political parties are operating. (Mitra, 2012) Essentially, the Indian political tradition is ingrained in the Western legacy of Post-Enlightenment philosophy, and the unique system of governance in India can be attributed to the fact that the political is enmeshed in the broader cultural, social and economic matrix. (Chakrabarty, 2008).

The Indian political arena which was once dominated by the preponderance of the Indian National Congress as a catch-all inclusive and centrist organization, in the one-party dominance of the party, or the 'Congress System' (1947-1967) as envisaged by Rajni Kothari during the reign of Jawaharlal Nehru, soon witnessed a sharp decline and transition towards an increasingly competitive multi-party system with the rise of various regional parties and non-Congress governments in different states. (Kohli, 2009) The hegemony of the Congress however was soon restored during Indira Gandhi's increasingly authoritarian exercise of power and 


\section{International Journal of Current Science Research and Review}

ISSN: 2581-8341

Volume 04 Issue 06 June 2021

DOI: 10.47191/ijcsrr/V4-i6-03, Impact Factor: 5.825

IJCSRR@ 2021

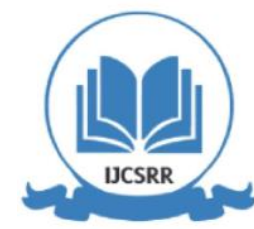

www.ijcsrr.org

continuation of Soviet Socialist model of policymaking, wherein the Congress leadership was highly centralized and the provincial party units did not enjoy a considerable degree of autonomy like the Nehruvian era. (Chatterjee, 2010) With two alliance structures at each end and multiple free floating state-based and small political formations at the regional level, the dawn of the coalition era of Indian politics started with the demise of Indira Gandhi, wherein horse trading, hung legislatures, weak minority governments at the centre, competitive bargaining and electoral interest driven power politics constituted the underlying rational behind coalitional arrangements. (Ibid) The beginning of this trend in the Indian provinces in the post-1967 era with the fragmentation and schism within the Indian National Congress and capture of political power by state-based political parties soon became a well-entrenched feature, which was exemplified by the major coalition of parties brought under one umbrella, where ideology became secondary, only to episodically re-confirm and re-invigorate the growing regionalization of the Indian polity. (Hasan, 2002) The gradual emergence of coalitional arrangements at the centre in 1989, 1996 and 2004 signalled a significant departure from the unilateral dominance of the Indian National Congress in the past, and the electoral outcomes unequivocally endorsed the increasing importance of a multi-party system as integral to India's democratic governance. (Ibid)

The fragmentation of the Congress coalition, coupled with rampant factionalism, lack of inner-party democracy, leadership vacuum, institutionalized corruption, trust deficit and accountability crisis had paved the way for the pyrrhic rise of multiple regional parties, predicated on increasing political mobilization on ethno-linguistic and caste-based lines. Caste and communal militancy, caste-based assertions and identity politics became a regular phenomenon with the formation of caste coalitions and political formations, taking into account the agglomerating political agency among the Dalits and the Other Backward Classes (OBCs). While social and political cleavages formed the centre of gravity of electoral arithmetic, the Rashtriya Swayamsevak Sangh (RSS) affiliated Bharatiya Janata Party (BJP), which was formed in 1980 as a merger of Janata Party and its precursor Bharatiya Jan Sangh, soon embarked on its massive transformative project of Hindutva or aggressive militant Hindu nationalism, paving the way for the Ram Janmabhoomi Movement, communalization of the Indian polity and Hindu fundamentalism, subsequently leading to the destruction of the Babri Masjid at Ayodhya in 1992 following harrowing nationwide communal riots and asserting the demand for a monolithic Hindu Rashtra or a Hindu ethno-state. The National Democratic Alliance (NDA) government under Atal Bihari Vajpayee (1999-2004) helmed by the BJP was succeeded by the United Progressive Alliance (UPA) government under Manmohan Singh, spearheaded by the Indian National Congress (INC) for two successive terms, which was booted out of power in 2014, following intense anti-corruption movement for the demand of the Jan Lokpal Bill, multiple allegations of scams and corruption scandals and the meteoric rise of the BJP under the charismatic messianic image engineering of Narendra Modi, that scripted history by single-handedly winning 282 seats in the Lok Sabha Elections of 2014, signaling a tectonic shift in the political landscape and the configuration of India's political system.

\section{UNRAVELING THE INDIAN STATE: BROAD EPISTEMOLOGICAL AND ONTOLOGICAL OVERVIEW}

A dominant actor, embracing a huge network of authoritative institutions making and implementing policies and collective decisions on a nationwide basis, the state as a sovereign political institution in the working of Indian political process has been formalized and rationalized, being the central player in the Indian political arena. (Jayal, 1999) Essentially, political power is integrated into the comprehensive social order vis-à-vis the state as the integral medium, and the state typifies a certain political mission, a teleological vision, wherein its structural and institutional arrangement through a vast array of mechanisms, instrumentalities, agencies and officials employ myriad techniques to accomplish the goal in the societal domain. (Ibid) The Indian state plays a highly paradoxical role in the Indian political process. On one hand, at the individual and community level it performs a collectivizing function while being a coercive institution. On the other hand, it provides myriad benefits and protection to its members or bona fide citizens residing in it, ranging from citizenship rights, welfare programmes and social services. (Parekh, 1993) Despite representing the interests of the dominant classes, the state also functions as the site or the collective arena where the general interest of the community at large can be formulated, and thus the multipronged and dialectical role played by the state make the task of theorizing or conceptualizing it a herculean challenge. (Ibid)

Being the key player in the modern drama of development and welfare, the state has a changing role in the context of post-colonialism and macroscopically, there are two dominant perspectives or interpretations to understand the functioning of the Indian state, namely, 


\section{International Journal of Current Science Research and Review}

ISSN: 2581-8341

Volume 04 Issue 06 June 2021

DOI: 10.47191/ijcsrr/V4-i6-03, Impact Factor: 5.825

IJCSRR@ 2021

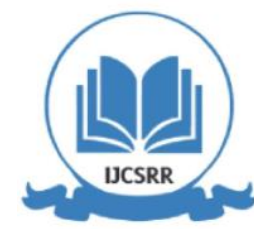

www.ijcsrr.org

the Liberal and Marxist approach. (Chatterjee, 2010) These two broad perspectives however have been criticized in the contemporary times, especially by postmodern scholars for their reductionist and deterministic approach of tending to reduce politics to social variables. Despite having differences, the two dimensions are quite similar in focusing on variables like the level of economic development and social determinants of the political process. While the liberal-modernist perspective exclusively focuses on the role of institutions and processes as the key to discern the state and political power in India, while explaining state power in terms of the policy of non-intervention; with an added emphasis on parliament, universal adult suffrage, free trade and free open market, and civil society, the Marxist perspective considers the political economy as the decisive factor and the principle of class analysis as the core determinant in understanding the state, simultaneously questioning who will hold or exercise the state power. (Ibid) As the liberal perspective is individualistic in nature and advocates liberty, the Marxian perspective is inherently collectivist in nature, while calling for equality. (Thakur, 1995).

Borrowing the theoretical foundation from Liberal Modernization theory, the early descriptions of state focused on the function of political institutions and democratic processes, and essentially, the amalgamation of democratic ideology, economic development and distributive justice had provided a unique opportunity of transforming traditionally apolitical society, in which the state became the cardinal instrument and principle agent or vehicle of transformation. (Kumar, 2016) In this regard, the added emphasis on the primacy of political processes had distinguished the specificity of democratic experiments in terms, which were different from the prevailing overarching Western framework. In this connection, W.H. Morris Jones had stressed on the capability of political institutions, especially one-party dominance and more generally representative institutions in order to introduce social and economic transformation, and the transformation in the societal sphere affected change in the conceptualization of the state in the political realm. (Ibid) The liberal theory, conceptually and ideationally is highly descriptive and normative in nature, while embracing a vast array of political institutions, ranging from popular elections, accountable government, majoritarian decision-making and a set of principles to civil liberties, legal equality and the rule of law. (Hasan, 2000) However, the liberal-institutional perspective while focusing on the formal and functional aspects of the role of the state failed to explain and analyze the significant changes in the Indian polity since the 1960s, namely - Beginning of radical class politics and left-wing agitations, coalition politics, social crises in terms of famines, droughts, food shortages, unemployment, poverty and wars. (Kohli, 1987).

Subsequently, two important perspectives emerged in the field of Political Science to explain the role of the state, namely the Societycentric and the State-centric viewpoints. The fundamental characteristic feature of the former is that it primarily focuses on societal change and societal dynamics, and thus highlighted a wide range of plethora of mechanisms of social change, viz. Zamindari (landlord) abolition; abolition of poverty; assertion of lower orders (Mandalization) in promoting or hampering the functioning of the state. (Sudarshan, 2002) Unfortunately, however, there was a considerable degree of dissatisfaction with the society-centric approach, and the decade of 1980s gradually gave rise to a new State-oriented academic literature that had exclusively emphasized on the autonomy of the state while arguing that Society-centric theories were fallacious and simply deficient because they reduced politics to variables of the society, and in this regard, Max Weber had defined the state as an organization, rather a special arrangement with distinctive interests and goals that influence the politics of the society as a whole. (Ibid) In a similar vein, multiple studies have demonstrated the shortcomings and practical limitations of the Statist approach, wherein it is considerably constrained by a fragmented heterogeneous society, and the chief critique of the Indian state comes from eminent Neo-classical economists like Jagdish Bhagwati and T.N. Srinivasan, who had illustrated by categorically pointing out how the strategy of combining planning and import substitution had dramatically resulted in a high-cost economy marred by corruption, inefficiency and distortions. (Jayal, 1999).

On the other hand, for the Marxists, the complexity and convolutions pertaining to class formation and class action are the essential elements for understanding the state, and though there are differences of perceptions within the Marxist intellectual tradition, the issue of imperialism occupies the centre stage in this debate. (Sudarshan, 2002) The analysis of the state is understood both in terms of the long term structure of the compositions of Indian politics, which are partially determined by Capitalism and inclusion of the economy into the international Capitalist order, and the changing balance in the class coalition dominating the state. (Alam, 1994) As a counternarrative of these views, scholars and academicians subscribing to a Subaltern approach had subjected bourgeois politics and the nation state to a sustained cultural critique, and they had argued that the Indian democracy was the not the outcome of a national 


\section{International Journal of Current Science Research and Review}

ISSN: 2581-8341

Volume 04 Issue 06 June 2021

DOI: 10.47191/ijcsrr/V4-i6-03, Impact Factor: 5.825

IJCSRR@ 2021

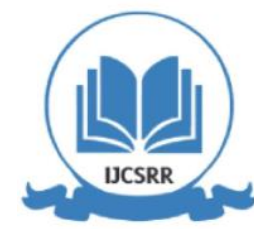

www.ijcsrr.org

popular revolution but one that was carried out by Mahatma Gandhi under the banner of Indian National Congress, that made the bourgeoisie establish its hegemony over the subaltern, viz. the peripherally marginalized, ostracized and discriminated groups of the Indian society. (Hasan, 2000) Delving with the state as an essential concept, the Subaltern scholars spotlighted their attention outside the circles of elite politics, while emphasizing the potential of the subaltern classes and their ideologies of resistance in reshaping the state. (Ibid) Subscribing to the Neo-Marxist viewpoint, Pranab Bardhan opines that the state is essentially an autonomous actor, which in some historical cases plays an important role in shaping and holding class power rather than vice-versa. (Bardhan, 1989).

However, the formation of a politically independent nation-state in India had been a serious challenge, and despite being a fundamental agent of transformation, the state continues to remain a contested terrain for social and political conflict of all sorts. NonMarxist scholars like Atul Kohli and Rajni Kothari and even the Marxist and Neo-Marxist scholars like Sudipta Kaviraj, Pranab Bardhan concurring with the society-centric view have all agreed upon a plethora of problems concerning the autonomy of the Indian state, whose role have been eroded with the augmented pre-eminence of market forces in the Indian economy, following Liberalization, Privatization and Globalization, opening up a novel dimension with the new economic reforms of Structural Adjustment Programme during Post-Liberalization under P.V. Narasimha Rao in 1991, encouraging Foreign Direct Investment (FDI), free and open trade, thereby augmenting the importance of free-market economy. (Kohli, 2009) According to theorists and experts across the ideological spectrum, the predicaments plaguing the Indian state chiefly centre around the real problem of the ongoing process of economic development, that is taking place without benefitting the majority of the segment of the population, mainly the worst off, who are not enjoying the fruits of economic prosperity owing to the continuation of massive socio-economic inequality and comprehensive backwardness. Further, the issue of acute legitimacy and accountability crisis of the state in terms of credibility and respect in the eyes of the citizens, coupled with the degradation and complete breakdown of authority has led to the state's autonomy's erosion through the civil society. Additionally, the rueful destabilization of the state's organizational and ideological pillars and its foundational attributive elements, like secularism, developmentalism and welfarism, along with the gradual decline of the civil and political institutions like the civil bureaucracies and the party system, have further aggravated the situation. Also, the rampant politicization of the main apparatus of the state civil service while causing pyrrhic rise in corruption levels and scams of politicians, bureaucrats and government officials, coupled with patronage, cronyism, and institutionalized corruption becoming the pervasive operational rationale or dynamics of the economy and politics, backed by a malevolent civil service that is suborned to the influence of shrewd and selfish political elites, turning political processes into an arena of domination for the capitalist business interests, damaged the state's role in the Indian polity. (Ibid).

According to Partha Chatterjee (2010), the state institutions and the overall state structure has been subjected to comprehensive erosion in all sectors ranging from administration to law-making, public services to policy and decision-making, the principle accusation is that the standards of probity and accountability have been allowed to decline significantly, and the most valid reason behind this process of debilitating standards has been the constant pressure on the state authorities vis-à-vis the electoral process, in order to satisfy the immediate political demands of organized popular groups. Adopting a similar line of narrative, Ramachandra Guha (2007) opined that the norms, rules and regulations of state practice that were established in the early years of the Indian republic, when the mobilized demands had been confined to an extremely small section of the electorate, with the policy being determined and governed by a limited number of elite or patrician politicians, must also have proved adequate enough in an era when the process of democratic consolidation and democratic mobilizations are both widening and are deeper, and this underlying assumption has been proved wrong. Analyzing the dialectical interplay between the state and the society in India, it can be said that while the normative conception of the state required that essentially the society comprising of equal citizens should be ideally treated as homogeneous, the dynamic and continuously evolving practices of democratic politics required the identification and due recognition of a heterogeneous social, and this is exactly reflected in the categorical differentiation between the civil and political society in the Indian political system. (Guha, 2007).

In the age of globalization where the preponderance of market forces has led to a seamless borderless interconnected world, in the Indian context, the major repercussion of economic liberalization in the 1990s has been the systematic withdrawal of the Indian state from myriad sectors of economic activity, and even in the areas or avenues where the state has remained responsible for providing 


\section{International Journal of Current Science Research and Review}

ISSN: 2581-8341

Volume 04 Issue 06 June 2021

DOI: 10.47191/ijcsrr/V4-i6-03, Impact Factor: 5.825

IJCSRR@ 2021

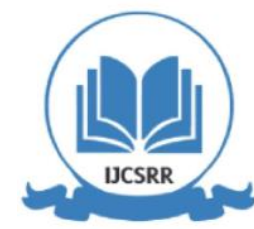

www.ijcsrr.org

services, there has been an outsourcing of this duty by the state to private agencies and Non Governmental Organizations (NGOs), and this has occurred at a time when political mobilizations have contributed to electoral majorities spearheaded by lower caste groups, Dalits and other peripherally marginalized communities in different Indian states. (Ibid) Quite paradoxically, as there has been an increasing pressure exerted on the state institutions to provide higher direct benefits like reservations in government employment, administration and educational institutions for backward and marginalized groups, there is another pressure exerted on the state vis-à-vis judicial, fiscal and other regulatory institutions, in order to diminish and curtail its vast array of activities, while allowing those sectors to be operated by the apparently more prudent and efficacious private bodies and organizations. (Chatterjee, 2004) In this regard, a remarkable development has been the gradual emergence in the recent years, of one particular branch of the state functioning as a self-conscious check on the perceived excesses of others, and while the state and central executives and legislature are being held responsible for flouting the norms of rationality, equity, equality and probity while satisfying multiple electoral constituencies, the law courts are have become pro-active in reasserting those rules and norms that direct the governmental agencies to undo the amount of damage caused. (Ibid) Playing a constructive role and acting in response to a plethora of demands in a peculiarly heterogeneous political society, the government authorities have performed effectively, accompanied with the legal institutions in the form of various High Courts and the Supreme Court of India, who have gradually emerged as the custodian and defenders of homogeneous and normative civil society consisting of equal citizens, especially with the help of the special instrument of Public Interest Litigation (PIL), in which the Supreme Court of India is empowered to take into account or cognizance of any particular issue or matter it deems to be necessary in the general interest of the public, while investigating, scrutinizing it and sending orders to respective agencies of the government. (Kashyap, 2008).

The series of economic reforms in the Post-Liberalization era have contributed to the gradual withdrawal of the state from multiple sectors and fields where it was regarded as the dominant or sole player, but the paramount importance of the state in India as the facilitator or enabler, arbiter, chief allocator of resources for the society at large and the principle regulator, has not diminished and the state continues to remain a major player in the Indian political process. From a Gramscian lens, the restructured and reconstructed state of the passive revolution wherein corporate capital has assumed the position of hegemonizing the civil society while dominating the state structure at large, the state has continued to remain the large framework within which every single dominant social class and the highly organized democratic forces are continually engaged in their social and political struggles, and thus, the urban middle classes have not abandoned the democratic or the state's political institutions. (Chatterjee, 2010) In the contemporary Indian political system, multiple processes and institutions within the state structure are utilized and used selectively by dominant minority groups like the urban middle classes or corporate capitalists in an age of consolidated and semi-monopoly capital, in order to diminish the control and authority of agencies of the government that operate as true representatives of democratic majorities, and they could be specific offices of bureaucracy or courts of law that are projected in the public domain via print, electronic and digital media. (Ibid) The proposition advanced by Frankel and Rao (1990) that democratic politics in India was veering towards a division or schism between public institutions with entrenched privileged groups like upper middle class, and the political institutions being spearheaded and controlled by the representatives of lower castes and underprivileged groups, had been proved too simplistic and fallacious in the working of modern Indian political process. In reality, rather than observing a split between state and the non-state domains, the emergent and nascent social opposition forces are being played out between various branches and divisions of the Indian state, along with tactical and spatial withdrawals and engagements in the process. (Fuller \& Benei, 2001) Thus, the Indian state had undergone a plethora of transformations in its role, autonomy and in its relationship with the market in the Indian political process, from being the sole actor and dominant player in the functioning of the Indian polity to becoming subjected to the erosion of state institutions, its dynamism and tale of transmutation has been indeed a remarkable pattern in the Indian political system.

\section{CONTEMPORARY NATURE OF THE INDIAN POLITICAL ESTABLISHMENT}

Ever since the Indian Freedom Movement and India's subsequent decolonization, as a part of Indian political tradition, the political system took certain social cleavages and socio-political identities for granted, and whenever it was assumed that India cannot be taken over by any authoritarian regime owing to a natural centrism to Indian politics, it was believed that social power in India has always been fragmented enough so that it could act as a check and balance on any consolidation of power. (Sigur Center for Asian Studies GWU, 2021) Traditionally, caste was a form of fragmenting social power, region and religion sometimes played the same role as 


\section{International Journal of Current Science Research and Review}

ISSN: 2581-8341

Volume 04 Issue 06 June 2021

DOI: 10.47191/ijcsrr/V4-i6-03, Impact Factor: 5.825

IJCSRR@ 2021

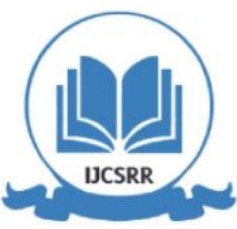

www.ijcsrr.org

forms of fragmenting social power, wherein the underlying assumption was always that the ruling coalition in a sense would be built from a synthesis of these fragments, while having a certain natural social check on the consolidation of social and political power, and as a result, the politics of resistance to the ruling regime always relied on caste-based alliances or blocs, class coalitions, regional forces or linguistic assertions. (Ibid) However, over the last ten years, especially in the de facto BJP-led NDA regime under Narendra Modi, all natural social and political resistances to politics have been dissolved, or in a sense have been domesticated. (Institute of Development Studies, 2018).

While BJP's electoral hold and national political presence has been deepening and consolidating gradually, essentially this particular regime is one which came into being when the old regime of Congress dominated UPA had imploded from the top and self-serving plutocratic indecisive structures of the Indian National Congress (INC) had demonstrated their limitations in such a manner that even after seven years of their massive electoral defeat, there is lack of effective political will and no efficacious coherent national political opposition left, as the old regime had become cold and frozen in its ideological thinking. (Sigur Center for Asian Studies GWU, 2021) Hegemonizing the Indian political system, the BJP has managed to establish its control over both the capital and the information order, while commanding a vastly powerful mobilization machine and making politics mediatized and vigilantism legitimized. (Ibid)

In the present transformative moment of the Indian political regime, the conjunction of authoritarianism, populism and communalism and the manifestation of the resultant normative byproduct have been manifested in the state's political practice, quite peculiarly having an enormous popular appeal in the BJP-led NDA era under Narendra Modi from 2014. As the inherent centrist or moderate ideological circumference of Indian politics has been categorically subverted due to the meteoric rise of majoritarianism propelled Hindutva (Hindu ultra-nationalism) as a transformative project, wherein the vicarious appeal of Hindu nationalism has promised the masses the fantasy of a larger collective project by catering to their political imagination, the organic cross-cutting ties and political cleavages of the Indian political establishment that have acted as a machine of agglomeration, have gradually been diluted and deagglomerated. (New Socialist Initiative India, 2020) According to Pratap Bhanu Mehta, the centrality of ideational values of faith, trust and accountability, clubbed together under the umbrella of "Politics of Vishwas", associated with the Narendra Modi-led BJP regime has negated the institutional constrains on the exercise of power, as anti-elitism and anti-pluralism has formed the pillars of its majoritarian monolithic bloc, where exclusionary manoeuvres, binarization of identities, communal polarization and discriminatory policies of Hindu nationalism inscribed in law, policymaking and state practices are an integral component. (Ibid) The executive aggrandizement of power, the obliteration of centrist consensus of the Indian political process, demagogy and personality cult driven politics of delivering a barrage of right-wing populist rhetoric under Narendra Modi has characterized the contemporary Indian political system. (The Quint, 2018) Representing an alarmingly debilitating qualitative hardening of India's political culture, in Achin Vanaik's opinion, the omnipresence and gargantuan organizational proliferation of the Rashtriya Swayamsevak Sangh (RSS), the mother organization of the BJP, has weakened India's democratic ethos while ensuring a massive implantation across different power structures and societal levels, ranging from making inroads in the civil society and vigilanticizing it to disemboweling the rural soil through rural populism. (Institute of Development Studies, 2018)

As the phenomenon of cultural nihilism among the Indian political elites has engulfed the Indian political establishment, the disillusionment of the social by the political has been a remarkable development, wherein the BJP has successfully played a constructivist role in the discursive articulation of newer constituencies, as a significant departure from the social and economic determinism of age-old centre-left political tradition. (Institute of Parliamentary Affairs, 2021) While not taking the naturalness of the fragmentation of Indian polity for granted and relying on political cleavages for electoral assertions and political mobilization, the Modi regime has played a homogenizing role, simultaneously centralizing India's federal arrangement, while offering a certain specific kind of semiotic recognition of the political agencies of the marginalized and peripherally backward masses, without actually empowering them. (Ibid) Having ideological roots to the doctrine of Hindutva propounded by V.D. Savarkar that shares the luminous vision of a Hindu Rashtra or organic Hindu state for the ethnic inhabitants of Hindustan, equating Hinduism as a geographical identity, the discursive success of the BJP has centered around mobilization on religious grounds, preponderance of Brahminical hegemonic social order and linguistic chauvinism in an imperialistic manner, having its genesis in the Hindi heartland of North India. Quite ironically, as Hindu Nationalism had been opposed to the concept of market liberalization, free and open market and trade, 


\section{International Journal of Current Science Research and Review}

ISSN: 2581-8341

Volume 04 Issue 06 June 2021

DOI: 10.47191/ijcsrr/V4-i6-03, Impact Factor: 5.825

IJCSRR@ 2021

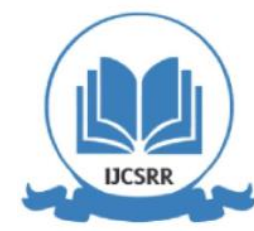

www.ijcsrr.org

globalization, the present political system has been characterized by a paradoxical unity of its homogeneous project of Hindutva with neo-liberal developmentalism, that has crystallized the foundation of semi-consolidated monopoly capitalism, while functioning virtually as a Minarchist state. (New Socialist Initiative India, 2020)

Drawing parallels between the one-party dominance of the Indian National Congress under Rajni Kothari's model of the Congress System and the present hegemonic rule of the BJP over the Indian political system, Achin Vanaik has advanced certain important caveats. According to him, both the Congress and the BJP have been successful while drawing their respective support from the large and powerful states of the Hindi heartland in northern India, quantified by the first-past-the-post electoral system, and both the political parties have dominated the national political landscape sans rival party of the same tall order, unlike Britain's or USA's brand of twoparty system. (Vanaik, 2018) As both the parties have been spearheaded by charismatic leaders with personalistic tendencies, claiming a special right to lead and rule India - Jawaharlal Nehru by virtue of his contribution in India's struggle for independence and his social status; Narendra Modi through his increasingly overt patriotic devotion in the cause of making India strong and a superpower. (Ibid) Similarly, both the hegemons have exploited the intelligence services, bureaucracy and the judiciary for their own vested political interests, shared closed ties to big capital, both have vilified and made China and Pakistan their permanent enemies, used repression as a controlled drip that had been injected into the body politic at specific moments while using crushing force in imposing national control over the volatile and rebellious border regions, while permitting and normalizing pogroms on occasions, against the Muslims, that went neglected under the legal scrutiny and thus unpunished. (Marx School, Sri Lanka, 2020)

However, notwithstanding the similarities, there has been undoubtedly a paradigmatic shift in India's political atmosphere and party system, and the present regime has been instrumental in addressing the decades of institutionalized corruption that ravaged the Indian polity, by promising the mass electorate a vision of a 'New India' that buttresses on self-reliance and indigenous capacity building.

\section{CONCLUSION}

In this paper, the comprehensive transformation, the structural-functional dynamic and the changing dimensions of the Indian state, its role in the context of India's protean nature of federalism has been analyzed, while throwing light on the characteristic features and unique elusive nature of the contemporary political establishment, that has marked a significant departure from India's early tryst with parliamentary democracy, secularism, cooperative federalism and pluralistic ethos, thereby emboldening the foundation of an authoritarian populist and majoritarian regime, characterized by the hegemony of the ruling BJP.

\section{REFERENCES}

1. Alam, Javeed (1994): 'Nation: Discourse and Intervention by the Communists in India' in T.V. Sathyamurthy (ed.) State and Nation in the Context of Social Change. New Delhi: Oxford University Press.

2. Bardhan, Pranab (1989): 'The dominant class', Economic and Political Weekly: pp.156-160.

3. Chakrabarty, Bidyut (2008): Indian Politics and Society Since Independence: Events, Processes and Ideology. New York: Routledge.

4. Chatterjee, Partha (2004): The Politics of the Governed: Reflections on Political Society in Most of the World. New York: Columbia University Press.

5. Chatterjee, Partha (2010): 'The State' in Mehta, Pratap Bhanu and Niraja Gopal Jayal (eds.) The Oxford Companion to Politics in India. New Delhi: Oxford University Press.

6. Frankel, Francine and M.S.A. Rao (eds.) (1990): Dominance and State Power in India: Decline of a Social Order. New Delhi: Oxford University Press.

7. Fuller, C.J. and Veronique Benei (eds.) (2001): Everyday State and Society in Modern India. London: Hurst.

8. Guha, Ramachandra (2007): India after Gandhi: The History of the World's Largest Democracy. New Delhi: Picador India.

9. Hasan, Zoya (2000): 'Introduction: The Political Career of the State in Independent India' in Hasan, Zoya (ed.) Politics and State in India. New Delhi: Sage Publications.

10. Hasan, Zoya (ed.) (2002): Parties and Party Politics in India. New Delhi: Oxford University Press. 


\section{International Journal of Current Science Research and Review}

ISSN: 2581-8341

Volume 04 Issue 06 June 2021

DOI: 10.47191/ijesrr/V4-i6-03, Impact Factor: 5.825

IJCSRR@ 2021

www.ijcsrr.org

11. Institute of Development Studies (2018): 'The deep roots of authoritarian populism in India - Achin Vanaik.' Accessible at: https://www.youtube.com/watch?v=vBb1I9zlmyE (3 May, 2021).

12. Institute of Parliamentary Affairs (2021): 'The Crisis of Liberal Democracy in India by Prof. Pratap Bhanu Mehta.' Accessible at: https://www.youtube.com/watch?v=XPKE-C3tYXo\&t=490s (7 May, 2021).

13. Jayal, Niraja Gopal (1999): Democracy and the State; Welfare, Secularism and Development in Contemporary India. New Delhi: Oxford University Press.

14. Kashyap, Subhash C. (2008): Our Political System. New Delhi: National Book Trust, India.

15. Kohli, Atul (1987): State and Poverty in India: The Politics of Reform. Mumbai: Orient Longman Publishers.

16. Kohli, Atul. (2009): Democracy and Development in India: From Socialism to Pro-Business. New Delhi: Oxford University Press.

17. Kumar, Anand (2016): 'Nation-building in India and its Contemporary Challenges' in Azad, Rohit et al. (eds.) What the Nation Really Needs to Know: The JNU Nationalism Lectures. Noida: Harper Collins Publishers India.

18. Marx School, Sri Lanka (2020): 'Secularism, Communalism and Indian Politics Today | Professor Achin Vanaik | Marx School 11.' Accessible at: https://www.youtube.com/watch?v=p88xJXm0jak\&t=6414s (4 May, 2021).

19. Mitra, Subrata K. (2017): Politics in India: Structure, Process and Policy. New York: Routledge.

20. New Socialist Initiative India (2020): 'The Structural Contradictions of Indian Democracy and the Rise of the BJP by Prof. Pratap Bhanu Mehta.' Accessible at: https:/www.youtube.com/watch?v=Vo0NBDurEgQ\&t=4594s (6 May, 2021).

21. Parekh, Bhikhu (1993): 'Cultural Particularity of Liberal Democracy in India' in David Held (ed.) Prospects for Democracy. New Delhi: Polity Press Publication.

22. Sigur Center for Asian Studies GWU (2021): 'India's Domestic Politics and the Democratic Reckoning with Pratap Bhanu Mehta.' Accessible at: https://www.youtube.com/watch?v=dLpb7gslJ6o\&t=1808s (4 May, 2021).

23. Singh, Mahendra Pratap and Himanshu Roy (eds.) (2017): Indian Political System. Noida: Pearson India Education Services Pvt. Ltd.

24. Singh, Mahendra Pratap and Subhendu Ranjan Raj (eds.) (2012): The Indian Political System. Noida: Pearson India Education Services Pvt. Ltd.

25. Sudarshan, R. (2002): 'Stateness and Democracy in India's Constitution' in Hasan, Zoya et al. (eds.) India's Living Constitution. New Delhi: Permanent Black Publishers.

26. Thakur, Ramesh (1995): Government and Politics of India. London: Macmillan.

27. The Quint (2018): 'Modi’s Ideology-Driven Power Grab Has Redefined Indian Democracy | The Quint.' Accessible at: https://www.youtube.com/watch?v=eKE8axkbSOw (3 May, 2021).

28. Vanaik, Achin (2018): 'India's Two Hegemonies.' New Left Review. Accessible at: https://newleftreview.org/issues/ii112/articles/achin-vanaik-india-s-two-hegemonies (5 May, 2021).

Cite this Article: Abhigyan Guha (2021). Metamorphic Moment of the Indian Polity: Anatomizing the Evolution and Changing Dynamics of the Indian State against the Protean Nature of Cooperative Federalism. International Journal of Current Science Research and Review, 4(6), 499-507 